\title{
Hypoxanthine-Guanine Phosphoribosyltransferase
}

National Cancer Institute

\section{Source}

National Cancer Institute. Hypoxanthine-Guanine Phosphoribosyltransferase. NCI

Thesaurus. Code C38496.

Hypoxanthine-guanine phosphoribosyltransferase (218 aa, $\sim 25 \mathrm{kDa}$ ) is encoded by the human HPRT 1 gene. This protein plays a role in nucleoside metabolism. 